Stuck between Surplus and Shortage: Demand for Skills in the Russian Industry

V. Gimpelson (CLMS, Higher School of Economics, Moscow)

R. Kapeliushnikov (CLMS, Higher School of Ec onomics, Mosc ow)

A. Lukiyanova (CLMS, Higher School of Economics, Mosc ow)

Berlin, December 2008 


\section{Stuck Between Surplus and Shortage: Demand for Skills in the Russian Industry ${ }^{1}$}

In order to remain competitive, firms need to keep the quantity and composition of jobs close to the optimal for their given output. Since the beginning of the transition period, Russian industrial firms have been widely reporting that the quantity and composition of hired labor is far from being close to optimal. This paper discusses what kinds of firms in the Russian manufacturing sector are not able to optimize their employment and why. Do they suffer from a labor shortage induced by rapid growth, or are they still struggling with employment overhang? What are the occupations and skills in which there is a supposed surplus or shortage? What factors affect the probability that a firm will report non-optimal employment and be unable to solve this difficulty? Where is the labor excess/shortage concentrated and what makes it persistent? Finally, we discuss the costs of non-optimal employment. The analysis presented in this article is based on the data from a large-scale survey of Russian manufacturing firms.

\section{Introduction}

In the transition to a market economy, the Russian workforce has undergone a drastic reallocation across industries and occupations. ${ }^{2}$ Many specialized and technical skills previously acquired by workers during the central planning period have become partially or fully depreciated, and are no longer in demand by the industry. Skills mismatches in the labor market have become widespread, with sharp shortages of some types of skilled workers coexisting with excess supplies of the others. The educational system and specialized vocational and technical training institutions in particular seem to be poorly prepared to operate under the new market conditions and to supply skills that are required by the market.

The planned economy is sometimes known as the economy of shortage. ${ }^{3}$ With the start of transition in the early 1990s, the labor shortage in the Russian labor market abruptly turned into a surplus, expressed in growing unemployment and underemployment. By early 1999, unemployment reached 13-14 percent, the annual number of hours worked in industry shrunk by

${ }^{1}$ The paper is prepared as a part of the ESCIRRU project funded by the EU. It uses data collected within a joint World Bank - Higher School of Economics survey of Russian manufacturing firms conducted in 2004-05. The authors are grateful to I.Goldberg, V.Golikova, K.Gonchar, B.Kuznetzov, Ye.Savchenko, Hong Tan, A.Yakovlev, Ye.Yasin for comments and suggestions made during various stages of the study. Only the authors themselves are responsible for the conclusions and for any mistakes.

2 According to ?. Sabirianova (2001), over 40 percent of all workers in Russia changed their occupations in 1991-1998, of which two thirds did this in 1991-95. She termed this mass occupational change the "Great Human Capital Reallocation".

${ }^{3}$ See, for instance, Kornai, János, Socialist economy, Princeton University Press, 1992. 
10 percent, the real wage lost two thirds of its value, and complaints by firms of excess labor became universal. According to Fig. 1, based on quarterly data from the Russian Economic Barometer (REB) surveys, the proportion of firms reporting excess labor relative to expected output was always high prior to the 1998 financial crisis. Over 40 percent of firms noted that they had redundant personnel during that period. In comparison, only 5-10 percent of firms in the sample reported understaffing relative to expected output.

\section{Figure 1 \\ Over- and under-staffing in Russian industrial enterprises}

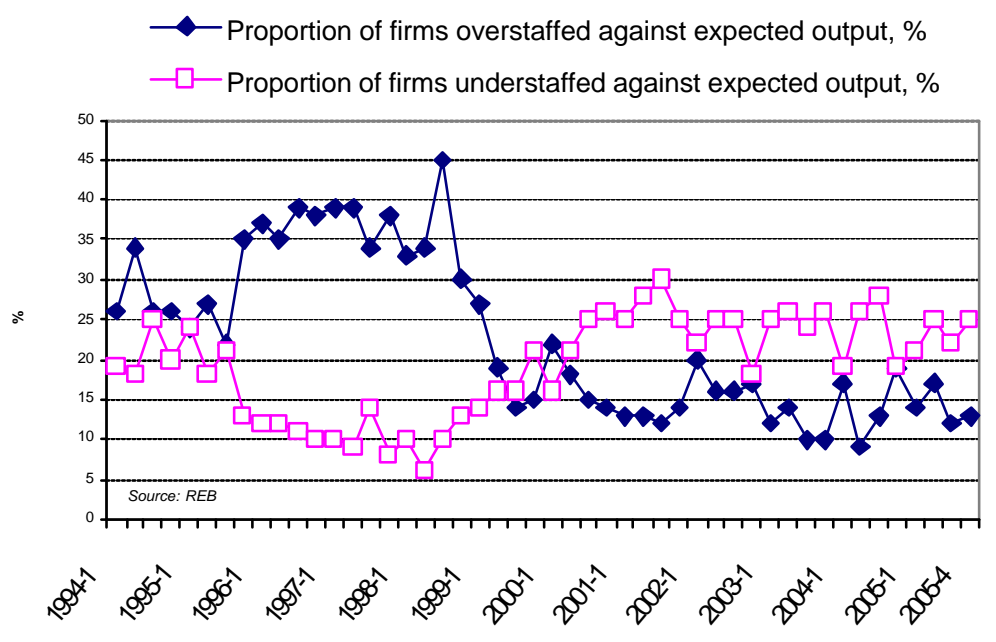

The post-crisis (since 1999) economic recovery changed the picture. GDP growth activated labor demand, improving labor utilization in all respects and stimulating rapid wage growth. However, industrial employment increased in 1999-2001 only marginally, and then returned to a downward trend and showed no reaction to significant economic growth. As a result, since 1999 the proportion of enterprises reporting a labor surplus has been on the decline, while the proportion of firms complaining about a labor shortage has been on the rise. Strong recovery in industrial output brought the proportion of overstaffed firms down to less than 10 percent. Meanwhile, the proportion of firms reporting that they were understaffed for expected output started to grow. In 2005, almost every fourth industrial firm reported under-staffing against expected output while less than 10 percent anticipated excess labor. According to another survey, understaffed enterprises made up over 40 percent while the proportion of overstaffed enterprises was close to zero. ${ }^{4}$ There was a general consensus that labor and skills shortages were

\footnotetext{
${ }^{4}$ V. Gimpelson. Shortage of Skills in the Labor Market: Undersupply, Limited Demand or False Signals From Employers? Working paper WP3/2004/01. Moscow: Higher School of Economics (in Russian). P. 10.
} 
a major constraint on output. The labor shortage seemed to have returned to labor market analyses. Demographic projections showing a decline in the workforce added to this argument.

This paper aims to shed light on how "optimal" employment is in the Russian manufacturing sector and what the scale, composition and factors of labor surplus and shortage are.

To this end, we will:

- Provide a general description of the surplus and shortage of labor;

- Determine what factors affect the likelihood of overstaffing or under-staffing;

- Analyze the costs for firms to deal with these problems;

- Study the association between surplus/shortage and firms' performance;

- Analyze the effect of employment protection legislation (EPL) on the likelihood of labor surplus/shortage.

This paper uses the Russia Investment Climate Survey (ICS) which provides detailed insights into these issues. In the next Section we describe the methodology and data. Sections IIIIV use data from the Russia ICS, to characterize the distribution and nature of overstaffing and under-staffing for different groups of manufacturing firms. In Section V these micro data are analyzed to gain insights into the potential reasons for reported staffing problems, including labor turnover, compensation policies and the inhibiting effects of labor regulations. Section VI turns to a discussion of various strategies for enterprises to meet their staffing and skill needs, including intensification of recruitment activities, using more overtime hours and worker training. A final section concludes with some policy implications of the findings.

\section{Methodology and Data}

Before moving to the empirical part of the paper we need to clarify our conceptual and empirical understanding of what we call labor "excess" and labor "shortage". There are no ideal measures for these concepts. We need to analyze all available evidence on the state of the labor market and to look at their expected behavioral effects. Both "excess" and "shortage" measures are often derived as managers' subjective responses to special surveys. This allows for identification of firms recording non-optimal employment, the size of the deviation of employment from the optimum, the distribution of "excess" or "shortage" firms by their structural (industries, regions, ownership forms, firm age and size) and performance related (productivity, profitability, etc) characteristics. For measuring excess we can also look at objective indicators such as employers-initiated separations (firings), and for capturing shortage we can examine vacancy rates. However, vacancy statistics are usually far from being complete and fully reliable, while wide use of downsizing critically depends on the stringency of EPL and 
its enforcement. Though caveats apply, self-reported measures are often the only tools available for an in-depth analysis of labor shortage/excess issues.

Frequent and loud complaints about the shortage of skilled workers and engineers from managers can be interpreted as an implicit indication of chronic labor market disequilibrium. If demand exceeds supply, then wages should rise in reaction to this shortage, thus boosting supply and containing demand. This is expected to bring equilibrium back into the market. If wages are fixed by the government and are thus rigid, as was the case under a planned economy, then the labor shortage becomes an ingrained systemic feature. However, if wages are flexible - and they are extremely flexible in the Russian labor market - the shortage story does not seem so convincing and needs special explanation. One of the possible explanations relates to the complex interaction between a demand curve that is rapidly shifting upward and the price rise. This interaction, which is institutionally mediated, may hinder the market in achieving equilibrium.

We note that in the 1950s the US economy experienced what was called "a shortage of engineers and scientists". This gave rise to various proposals for government intervention into the market's determination of labor quantities and their allocation. Reacting to this problem, Arrow and Capron (1959) wrote that "these views stem from our misunderstanding of economic theory as well as from an exaggeration of the empirical evidence. On the contrary, a proper view of the workings of the market mechanism, recognizing, in particular, the dynamics of market adjustment to changed conditions, would show that the phenomenon of observed shortage is exactly what would be predicted by classical theory in the face of rapidly rising demands." "Shortage" emerges when demand for labor rises (seen as a growing alternative wage) but the reaction speed of firms in hiring new workers at a higher wage rate is slow. "The reaction speed in any particular market depends partly on institutional arrangements, such as the prevalence of long-term contracts, and partly on the rapidity with which information about salaries, vacancies, and availability of personnel generally available throughout the market" from that study was that to deal with "shortages" more efficiently the institutional environment should help firms to respond more rapidly by containing costs that arise in dynamic adjustment to growing demand. In other words, if market clearing wages rise rapidly, institutions may induce "shortage".

${ }^{5}$ Kenneth J. Arrow; William M. Capron Dynamic Shortages and Price Rises: The EngineerScientist Case, The Quarterly Journal of Economics, Vol. 73, No. 2. (May, 1959), pp. 292-308.

${ }^{6}$ Ibid., P. 301 
One of the recent outbursts of "labor shortage" claims is discussed by Freeman (2006). He denies these claims, which are based on a flawed logic, as he believes. But aside from the logic, there are vested interests that may also matter. Freeman introduces a political-economy dimension in this dispute by arguing that "fears of a coming shortage fit with the concerns of various groups. Future shortage or not, business will benefit from policies that increase labor supply to drive down labor costs. Advocates of education and training see the shortage analysis as a way to gain national support for increased spending on training that will benefit workers. Politicians can use the shortage analysis to avoid dealing with policies like minimum wages, mandated health care spending, labor law reform, or enforcement of labor laws, and the like, by endorsing "win-win" education and training policies while sidestepping the fact that someone must pay for these investments."7

Since the incidence and scale of shortage usually cannot be estimated directly via reliable and objective variables, self-reported measures remain the main evidence on these issues. If managers say that their firms are experiencing a "shortage", then this opinion is usually accepted. By aggregating individual responses, we may achieve a general idea of the total "shortage" that emerges as "a major threat" to economic growth. ${ }^{8}$ This conclusion is then likely to be disseminated by industry analysts, education and training experts, the mass-media, and politicians. In the context of a non-transparent labor market, this adds to upward wage pressure.

Though self-reported measures are clearly very important and now widely used by economists, there is a risk of missing the complete picture by listening to what managers (firms) say and ignoring what they in fact do. What they do may reflect what they think, but their actual behavior is also shaped by many other factors, including those that are performance related. We believe that these two dimensions - subjective (what managers say) and objective (what firms do) - should be taken together and analyzed jointly. This approach sheds more light than any of the two dimensions taken separately and it defines the line we are going to follow in this paper.

We rely on data from the Russia ICA survey (ICS) of large and medium sized manufacturing firms. The survey was conducted by the World Bank and the Higher School of Economics in the second half of 2005. ${ }^{9}$ The sample contains around 1,000 firms and is

\footnotetext{
${ }^{7}$ R. Freeman. Is a Great Labor Shortage Coming? Replacement Demand in the Global Economy. Working Paper \#12541. September 2006, p.19.

${ }^{8}$ Rutkowski, J. From the Shortage of Jobs to the Shortage of Skilled Workers: Labor Markets in the EU New Member States, Discussion Paper No. 3202, December 2007.

${ }^{9}$ More details about the survey see in: "Building Skills and Absorptive Capacity in Russian Enterprises: Competitiveness and Investment Climate Assessment for the Russian Federation”,
} 
representative for the total population of Russian manufacturing enterprises. Data collection combined interviews with top-managers and objective economic and financial information about their firms. The main descriptive statistics of the sample are presented in Table 1.

Table 1. General characteristics of the Russia ICS sample

\begin{tabular}{|c|c|c|c|}
\hline & Average & Median & $\begin{array}{l}\text { Proportion of total } \\
\text { surveyed enterprises }\end{array}$ \\
\hline Industry & - & - & 8.5 \\
\hline Metallurgy & - & - & 8.8 \\
\hline Chemicals & - & - & 40.1 \\
\hline Machinery & - & - & 8.6 \\
\hline Wood processing & - & - & 9.3 \\
\hline Textiles & - & - & 24.8 \\
\hline Food & - & - & 43.8 \\
\hline Firm size & - & - & 25.7 \\
\hline Less than 250 & - & - & 15.9 \\
\hline $251-500$ & - & - & 14.7 \\
\hline $501-1000$ & - & - & 23.1 \\
\hline More than 1000 & - & - & 28.3 \\
\hline Foreign shareholder present & - & - & 21.7 \\
\hline State's stake in ownership mare than $25 \%$ & - & - & 51.9 \\
\hline New firm (after 1992) & - & - & 45.3 \\
\hline Positive R\&D spending & - & - & - \\
\hline Exporter & - & - & 54.3 \\
\hline Capacity utilization,\% & 64.1 & 70.0 & - \\
\hline $\begin{array}{l}\text { Enterprises with more than } 50 \% \text { equipment } \\
\text { obsolete }\end{array}$ & - & - & - \\
\hline Rate of investment in fixed capital & 33.2 & 9.1 & - \\
\hline Profitability, \% & 9.8 & 9.4 & - \\
\hline Value-added per worker, thousand Rubles & 201.4 & 137.9 & - \\
\hline Average monthly wage, Rubles & 6139 & 5248 & - \\
\hline Employment growth in $2004, \%$ & -1.5 & 0 & - \\
\hline$N$ & & 1002 & \\
\hline
\end{tabular}

Source: here and below authors' calculations based on the Russia ICS, 2005.

The issue of optimal staffing was discussed in two different parts of the questionnaire. First, respondents were asked to evaluate various constraints on their activity, among which a shortage of skilled labor could be chosen as one of the major constraints. Second, the questionnaire contained direct and detailed questions about labor surplus and shortage on average as well as by skills.

Respondents to the Russia ICS ranked "Lack of skilled and qualified workforce" as third on the list of investment climate constraints to enterprise growth and development (the first being taxation and the second being the unpredictability of state regulation). 67 percent of surveyed firms considered this constraint to be serious and 17 percent considered it to be the most severe.

World Bank, 2006; The Russian Industry at the Crossroads. What Prevents our Firms from Becoming Competitive, HSE, Moscow, 2007. 
However, for a number of reasons we prefer to rely more heavily on alternative estimates derived from the direct question about the shortage of skilled labor ${ }^{10}$. First, these direct estimates could help identify not only the firms that report a labor shortage but also those that report a labor surplus. Second, they can be used to analyze both the quantitative and qualitative dimensions of firms' staffing - the problem of labor shortage as well as the problem of shortage of skills. Third, they can be used to focus on particular occupational groups (managers, professionals, clerks, and workers). Fourth, linking these shortage/surplus estimates to firms' structural or performance indicators says more about what kind of firms are more likely to suffer from non-optimal staffing. Finally, there is a reasonable critique of the approach-based estimates of investment climate constraints ${ }^{11}$.

\section{Shortage and Surplus: Where and How Much?}

We begin our analysis of the survey data with a simple description of what respondents say about the optimality of current employment in their firms relative to current output.

\section{Scale of Shortage and Surplus}

The distribution of answers reporting a deviation of current employment from what managers would consider the "optimal" level given current output is presented in Table 2. A sizeable fraction of Russian enterprises have difficulties in adjusting the size of their workforce to the staffing levels dictated by their current output. In the 2005 Russia ICS, about 60 percent of surveyed firms rated their current staffing levels as "optimal" relative to current output. However, 27 percent of managers reported that their firms were "under-staffed" and 13 percent reported "over-staffing". This makes the ratio of firms with less-than optimal staffing to firms with more-than-optimal staffing around 2 to 1 . Based on these estimates, one might conclude that in the Russian industry the problem of labor shortage is significantly more acute than that of surplus.

Though firms reporting a labor shortage prevail compared to firms with a labor surplus, they are generally smaller in size. This hints at the fact that a labor shortage in some firms does not mean a labor shortage for the industry in general. Meanwhile, this suggests that these groups

\footnotetext{
${ }^{10}$ While answering the direct surplus/shortage question, respondents recognized the incidence of a labor shortage at their enterprises much less often than when they chose major investment climate constraints from the list.

11 W. Easterley. The Cartel of Good Intentions: Bureaucracy versus Markets in Foreign Aid. Center for Global Development. Working Paper No 4. 2002 April.
} 
may face high adjustment costs. Table 3 reports how far firms of both types are from their optimal employment size.

Table 2. Distribution of enterprises by optimality of staffing, percent

\begin{tabular}{|l|c|}
\hline $\begin{array}{l}\text { Given the current output of your firm, how would you evaluate the current } \\
\text { employment? }\end{array}$ & 59.8 \\
\hline $\begin{array}{l}\text { It is optimal } \\
\text { The firm needs more employees than it actually employs (the actual } \\
\text { employment is lower than optimal) }\end{array}$ & 27.3 \\
$\begin{array}{l}\text { The firm employs more employees than it actually needs (the actual } \\
\text { employment is above) }\end{array}$ & 12.9 \\
\hline $\mathrm{N}$ & 990 \\
\hline
\end{tabular}

Table 3 shows that mean deviations are close while the medians are similar. On average, under-staffed firms were short of personnel by 17 percent while over-staffed firms had 15 percent more workers than they currently needed. The distribution by size of the first group's deviation from optimal employment is biased to the left in comparison with the second group. The only reason that the mean shortage exceeds mean surplus is because three (3) firms reported a labor shortage in excess of 100 percent of their actual employment. If these three particular outliers are excluded, the two sub-sample means become almost equal. It is worthwhile to add that over-staffed firms are on average around 1.5 times larger than under-staffed firms. As a result, the difference between the gross shortage (the sum of insufficient workers over all firms reporting shortage) exceeds the gross surplus (the sum of redundant workers over all firms reporting excess) by only 17 percent. This may mean that the problem of labor misallocation is much more general than merely the labor shortage problem. (Evidently, occupational and skills characteristics of excess and shortage may also vary significantly.)

Table 3

Distribution of enterprises by difference between actual and desired employment, percent,

\begin{tabular}{|c|c|c|}
\hline $\begin{array}{c}\text { Difference between actual } \\
\text { and desired employment }\end{array}$ & $\begin{array}{c}\text { Labor shortage (\% of firms } \\
\text { reporting labor shortage) }\end{array}$ & $\begin{array}{c}\text { Labor surplus (\% of firms } \\
\text { reporting labor surplus) }\end{array}$ \\
\hline $1-5 \%$ & 26.9 & 12.6 \\
$5-10 \%$ & 33.1 & 37.6 \\
$10-20 \%$ & 19.4 & 36.2 \\
$>20 \%$ & 19.4 & 12.6 \\
\hline $\mathrm{N}$ & 263 & 127 \\
\hline
\end{tabular}

Enterprises are concerned not only with overall staffing levels but also with having the desired skills mix. This is borne out by which firms report under-staffing or over-staffing in several occupational groups: managers, professionals, other white collar employees, blue-collar skilled workers and unskilled workers (Table 4). Among the surveyed firms, 95 percent, 81 percent, 98 percent and 88 percent did not report any shortage of managers, professionals, clerks, 
or unskilled workers, respectively. The shortage of skilled manual workers seems to be more acute since it was mentioned by over half of all firms in the sample.

Table 4. Distribution of surveyed enterprises by staffing with various skill groups, percent

\begin{tabular}{|l|c|c|c|c|}
\hline \multirow{2}{*}{ Skill groups } & \multicolumn{4}{|c|}{ Staffing with this skill group is.. } \\
\cline { 2 - 5 } & below optimal & optimal & above optimal & total enterprises \\
\hline Managers & 4.6 & 87.7 & 7.8 & 100 \\
Professionals & 19.3 & 72.6 & 8.1 & 100 \\
Clerks & 2.0 & 90.3 & 7.7 & 100 \\
Skilled workers & 54.2 & 41.5 & 4.3 & 100 \\
Unskilled workers & 12.5 & 74.5 & 13.0 & 100 \\
\hline
\end{tabular}

Table 5 cross-classifies staffing levels in different skill groups according to whether firms describe themselves as being staffed optimally, under-staffed or over-staffed overall. As might be expected, firms that have less-than-optimal staffing levels are more likely than other firms to report under-staffing in all skill categories, especially skilled workers (97 percent) and professionals (38 percent). Interestingly, firms with optimal or more-than-optimal staffing levels also report having skill shortages in the same two skill categories (12-15 percent and 37-43 percent, correspondingly). Therefore, specific skill shortages, especially of professional and skilled workers, can coexist with overall optimal or over-staffing at the enterprise level.

Table 5. Distribution of surveyed enterprises by general staffing and staffing of particular skill groups, percent

\begin{tabular}{|c|c|c|c|c|c|}
\hline & \multicolumn{5}{|c|}{ Firms reporting optimal staffing in different skill categories } \\
\hline $\begin{array}{l}\text { Classification of enterprises } \\
\text { by general staffing }\end{array}$ & Managers & Professionals & $\begin{array}{l}\text { Other white } \\
\text { collar }\end{array}$ & $\begin{array}{c}\text { Skilled } \\
\text { workers }\end{array}$ & $\begin{array}{l}\text { Unskilled } \\
\text { workers }\end{array}$ \\
\hline - optimal & 93.5 & 85.2 & 96.9 & 62.5 & 88.4 \\
\hline - under-staffed & 86.0 & 59.6 & 91.9 & 3.0 & 65.2 \\
\hline - over-staffed & 63.8 & 40.8 & 56.1 & 24.6 & 28.9 \\
\hline Total & 87.7 & 72.6 & 90.3 & 41.5 & 74.5 \\
\hline & \multicolumn{5}{|c|}{ Firms reporting under-staffing in different skill categories } \\
\hline $\begin{array}{l}\text { Classification of enterprises } \\
\text { by general staffing }\end{array}$ & Managers & Professionals & $\begin{array}{l}\text { Other white } \\
\text { collar }\end{array}$ & $\begin{array}{c}\text { Skilled } \\
\text { workers }\end{array}$ & $\begin{array}{l}\text { Unskilled } \\
\text { workers }\end{array}$ \\
\hline - optimal & 3.1 & 11.9 & 0.7 & 37.3 & 5.2 \\
\hline - under-staffed & 8.3 & 37.7 & 4.7 & 97.0 & 32.0 \\
\hline - over-staffed & 3.9 & 15.2 & 2.4 & 42.9 & 6.6 \\
\hline \multirow[t]{2}{*}{ Total } & 4.6 & 19.3 & 2.0 & 54.2 & 12.5 \\
\hline & \multicolumn{5}{|c|}{ Firms reporting over-staffing in different skill categories } \\
\hline $\begin{array}{l}\text { Classification of enterprises } \\
\text { by general staffing }\end{array}$ & Managers & Professionals & $\begin{array}{l}\text { Other white } \\
\text { collar }\end{array}$ & $\begin{array}{c}\text { Skilled } \\
\text { workers }\end{array}$ & $\begin{array}{l}\text { Unskilled } \\
\text { workers }\end{array}$ \\
\hline - optimal & 3.4 & 2.9 & 2.4 & 0.2 & 6.4 \\
\hline - under-staffed & 5.7 & 2.6 & 3.5 & 0 & 2.8 \\
\hline - over-staffed & 32.3 & 44.0 & 41.5 & 32.5 & 64.5 \\
\hline Total & 7.8 & 8.1 & 7.7 & 4.3 & 13.0 \\
\hline
\end{tabular}

Firms that reported optimal or less-than-optimal employment levels usually did not complain about labor surpluses in particular skill groups. Meanwhile, 32-65 percent of firms 
with more-than-optimal employment reported surpluses in particular skill groups. Almost two thirds of them claimed some excess of unskilled workers. Redundant workers that could potentially be reallocated towards a more efficient usage of labor can be found in all skills groups.

A tentative conclusion is that labor shortage and labor surplus in the Russian industry are likely to coexist and both states bring losses to firms. In most cases, a labor shortage goes hand in hand with a shortage of skills.

\section{Causes for Shortage and Surplus}

Firms experiencing skill shortages tend to cite a number of reasons for under-staffing, which are collected in the left panel of Table 6. The four most commonly listed reasons by frequency of citation are: lack of workers with the needed skills in the local labor market (72 percent), paying low wages compared to other firms (41 percent), high labor turnover (30 percent), and high competition for workers in the local labor market ( 23 percent). These reasons are consistent with an inadequate supply of workers with relevant job skills in the local labor market, high rates of labor turnover, and payment of non-competitive wages and salaries. From this list one might conclude that the firms saw the major cause for labor shortage to be on the supply side - that the local labor market did not supply enough workers with the requisite skills, since reasons from the demand side were mentioned relatively rarely (the main reason here was the inability of firms to pay a competitive wage and to retain workers already hired). ${ }^{12}$ However, if we sum up all answers related to demand constraints, this sum exceeds the sum of answers related to supply constraints. As our analysis shows, those respondents who chose demand related explanations did not indicate a "lack of workers on the local labor market...". 13 Therefore, we believe that the conclusion about the undersupply of workforce as the major cause for labor shortage is not supported by hard evidence.

Reasons why the labor surplus remains sizable (the right panel of the Table 6) can be grouped as follows: a) deliberate hoarding of labor due to expectations of output growth (pos. 5), and b) involuntary hoarding due to significant turnover costs (pos. 1-4, 6). Firms choosing answers from group (a) tend to be growing or to be expecting output growth and are likely to be in better financial shape. In the second group, the situation was likely to be different and the firms expected downsizing. However, downsizing was too costly and therefore hardly feasible

\footnotetext{
12 Psychologically, managers may prefer to put blame on outside circumstances rather than recognize their own faults.

13 There is a negative and statistically significant correlation between choosing these two positions.
} 
due to economic, administrative, and social reasons. In other words, high firing costs make this strategy inefficient.

Table 6. Major reasons for labor surplus and shortage, percent *

\begin{tabular}{|c|c|c|c|}
\hline Reasons for under-staffing & & Reasons for over-staffing & \\
\hline High hiring costs & 2.2 & High firing costs & 18.8 \\
\hline $\begin{array}{l}\text { Lack of workers with needed skills in } \\
\text { the local labor market }\end{array}$ & 72.2 & $\begin{array}{l}\text { Resistance of trade unions to } \\
\text { downsizing }\end{array}$ & 4.7 \\
\hline $\begin{array}{l}\text { High competition for workers in the } \\
\text { local labor market }\end{array}$ & 23.0 & $\begin{array}{l}\text { Prohibitions from local or regional } \\
\text { authorities }\end{array}$ & 2.3 \\
\hline $\begin{array}{l}\text { Expectations for expanding product } \\
\text { demand }\end{array}$ & 4.8 & Fear of conflicts with workers & 10.2 \\
\hline High labor turnover & 30.0 & $\begin{array}{l}\text { Expectations for declining product } \\
\text { demand }\end{array}$ & 51.6 \\
\hline Hard/harmful working conditions & 18.5 & "Social responsibility" of managers & 47.7 \\
\hline $\begin{array}{l}\text { Low wages compared to other } \\
\text { enterprises }\end{array}$ & 41.1 & Other reasons & 26.6 \\
\hline Other reasons & 8.5 & & \\
\hline $\mathrm{N}$ & 270 & $\mathrm{~N}$ & 128 \\
\hline
\end{tabular}

* Figures do not sum to $100 \%$ because respondents could select 3 key reasons for under- or over-staffing.

\section{Composition of Shortage and Surplus}

How are claims of shortage and surplus distributed across firms? If not randomly, do they correlate with particular structural or performance-related characteristics of the firms? In an earlier paper, we argued that less efficient and less competitive enterprises were more likely to report a shortage of skilled labor. ${ }^{14}$ However, more efficient firms that were also more competitive on the labor market faced this problem less frequently. For them, a labor shortage meant an undersupply of unique skills and specific experience, which were a product of longterm development of the market economy and could hardly be produced in an accelerated fashion. Examples of these unique skills or experience are top-managers, corporate law or finance professionals, marketing or logistics specialists, etc. However, an adequate wage premium would allow such skills to be hired in other regions of the country or on the world labor market. As we are well aware, many Russian leading companies did exactly that.

We start considering this issue by providing simple descriptions of firms, the managers of which report non-optimal employment. Table 7 reports the distribution of staffing levels for the Russia ICS sample with respect to several firm characteristics. The probability of under-staffing and the level of under-staffing are highest for firms operating in the textile industry. In this sector, over 50 percent of all surveyed firms reported staffing levels below the optimal level, with the staffing gap averaging 22.6 percent relative to desired levels. New firms established in or after 1992, small enterprises with less than 250 employees, firms operating in the metallurgy

${ }^{14}$ V. Gimpelson. Op. cit. 
and machine-building sectors, and government-controlled firms (those with more than 25 percent public ownership) are also more likely to report understaffing. Over-staffing is more prevalent among large firms (with over 1,000 employees) and firms in the chemicals sector.

Table 7

Characteristics of Firms by Optimality of Staffing Levels

\begin{tabular}{|c|c|c|c|c|c|}
\hline \multirow[t]{2}{*}{ Firm characteristics } & \multirow{2}{*}{$\begin{array}{c}\begin{array}{c}\text { Optimal } \\
\text { staffing }\end{array} \\
\% \text { of firms }\end{array}$} & \multicolumn{2}{|c|}{ Under-staffed } & \multicolumn{2}{|c|}{ Over-staffed } \\
\hline & & $\%$ of firms & $\begin{array}{c}\text { by what } \\
\text { percentage }\end{array}$ & $\%$ of firms & $\begin{array}{l}\text { by what } \\
\text { percentage }\end{array}$ \\
\hline Total sample & 59.8 & 27.3 & 17.0 & 12.9 & 14.6 \\
\hline \multicolumn{6}{|l|}{ Industry } \\
\hline Metallurgy & 56.5 & 29.4 & 19.5 & 14.1 & 13.5 \\
\hline Chemicals & 52.4 & 25.0 & 8.9 & 22.6 & 13.7 \\
\hline Machinery & 57.1 & 29.6 & 17.9 & 13.3 & 15.3 \\
\hline Wood processing & 60.7 & 25.0 & 11.6 & 14.3 & 11.0 \\
\hline Textiles & 41.9 & 50.5 & 22.6 & 7.5 & 12.3 \\
\hline Food & 74.3 & 15.5 & 13.2 & 10.2 & 16.8 \\
\hline \multicolumn{6}{|l|}{ Firm size } \\
\hline Less than 250 & 62.9 & 29.0 & 22.0 & 8.1 & 13.6 \\
\hline $251-500$ & 58.4 & 28.2 & 15.2 & 13.3 & 16.8 \\
\hline $501-1000$ & 61.4 & 22.8 & 8.6 & 15.8 & 15.0 \\
\hline More than 1000 & 51.1 & 25.2 & 11.7 & 23.8 & 13.2 \\
\hline \multicolumn{6}{|l|}{ Exporter } \\
\hline No & 62.2 & 27.6 & 20.0 & 10.2 & 14.4 \\
\hline Yes & 56.9 & 26.9 & 13.4 & 16.2 & 14.7 \\
\hline \multicolumn{6}{|l|}{$R \& D$ spending } \\
\hline No & 63.6 & 26.8 & 16.9 & 9.6 & 14.4 \\
\hline Yes & 56.3 & 27.7 & 17.1 & 16.0 & 14.7 \\
\hline \multicolumn{6}{|l|}{ New firm (founded after } \\
\hline 1992) & & & & & \\
\hline No & 60.0 & 26.5 & 16.5 & 13.6 & 14.6 \\
\hline Yes & 59.1 & 30.2 & 18.6 & 10.7 & 14.8 \\
\hline \multicolumn{6}{|l|}{ Foreign ownership } \\
\hline No & 61.8 & 26.8 & 16.9 & 11.5 & 14.3 \\
\hline Yes & 53.3 & 29.0 & 17.3 & 17.8 & 15.3 \\
\hline \multicolumn{6}{|l|}{ State Stake in Ownership } \\
\hline Less than $25 \%$ & 61.0 & 26.7 & 14.9 & 12.3 & 14.5 \\
\hline $25 \%$ and over & 56.7 & 28.7 & 21.8 & 14.5 & 14.8 \\
\hline \multicolumn{6}{|l|}{ Competitiveness } \\
\hline High & 60.6 & 24.8 & 11.6 & 14.7 & 15.6 \\
\hline Medium & 61.2 & 26.9 & 15.6 & 11.9 & 14.7 \\
\hline Low & 47.9 & 35.0 & 25.0 & 17.1 & 14.7 \\
\hline
\end{tabular}

The fact that textile firms lead in the ranking of labor-shortage industries speaks for itself, as the textile sector is one of the most crisis-ridden in the Russian economy. The chemical and petro-chemical firms enjoyed relatively good financial health. They actually faced the reverse challenge, as they inherited a very large stock of employment that seemed to be excessive for their given or expected output (1.5 times larger than the sample average). 
Staffing levels are also related to how firms rank their level of self-reported competitiveness. Firms that rate themselves as having medium to high competitiveness are more likely to have optimal staffing levels 60-61 percent), and less likely to report either understaffing (25-27 percent) or over-staffing (12-15 percent). On the other hand, firms that classify themselves as non-competitive are less likely to have optimal staffing levels (48 percent) and more likely to be under-staffed (35 percent) or over-staffed (17 percent). Whatever the reasons that constrain under-staffed firms from employing more personnel, or constrain over-staffed firms from discharging redundant workers, non-optimal staffing levels can adversely affect firms' perceptions of their level of competitiveness.

Table 8. Staffing Levels and Firm Performance Indicators, 2004

\begin{tabular}{|l|c|c|c|c|c|c|}
\hline Staffing level & $\begin{array}{c}\text { Value-added } \\
\text { per worker } \\
\text { (VA/L) }\end{array}$ & $\begin{array}{c}\text { VA/L relative } \\
\text { to industry } \\
\text { average }\end{array}$ & $\begin{array}{c}\text { Profitability } \\
\text { in 2004, \%, }\end{array}$ & $\begin{array}{c}\text { Capacity } \\
\text { utilization, } \\
\%\end{array}$ & $\begin{array}{c}\text { Employment } \\
\text { growth in } \\
2004, \%\end{array}$ & $\begin{array}{c}\text { Average } \\
\text { monthly } \\
\text { wage, Rubles }\end{array}$ \\
\hline Optimal & 213.5 & 1.05 & 10.7 & 66.2 & 0.53 & 6246 \\
Under-staffed & 171.4 & 0.88 & 7.6 & 61.9 & -1.05 & 5620 \\
Over-staffed & 179.8 & 0.90 & 10.2 & 59.7 & -4.06 & 6295 \\
\hline $\mathrm{N}$ & 940 & 940 & 946 & 972 & 974 & 894 \\
\hline
\end{tabular}

Respondents to the Russia ICS listed non-competitive wages as a reason for their understaffing. If this is true, non-competitive wages may account for the inability of firms experiencing labor or skill shortages to either retain their skilled workers or to hire additional skilled workers on the open labor market. Firms with below-average performance may not offer competitive wages and therefore be unable to retain their most skilled workers or to fill vacant positions with skilled labor.

Multiple evidence suggests that under-staffing may emerge due to the inability of lowefficiency firms to pay competitive wages. Gimpelson (2004) used data from a survey of 300 large and medium size firms in Russia to investigate whether skill shortages were driven by supply or by demand-side constraints, and if so, what the enterprises were doing to respond to reported skill shortfalls. ${ }^{15}$ The analysis suggested that under-staffed firms had levels of labor productivity, profitability and average wages that were lower than those in both optimally-staffed and over-staffed firms. Furthermore, if low efficiency firms (those with low labor productivity, profitability or wages) declared that they had labor or skill shortages, they were more likely to use workers with mass (generic) skills supplied by the traditional vocational education system. In

${ }^{15}$ See: V. Gimpelson. Op. cit. The survey, conducted jointly by the HSE and the Russian Public Opinion Research Center (The Levada-Centre), surveyed 304 industrial enterprises located in 30 regions of Russia in 2003, with personnel managers as respondents. 
contrast, more efficient firms were more likely to search for workers with specific or unique skills whose supply was limited.

A similar pattern of association between reported staffing levels and firm performance emerged in the 2005 Russia ICS, which includes a much larger sample of industrial enterprises. Table 8 compares firms which differed in optimality of staffing by various performance indicators, including value-added per worker, labor productivity relative to the industry average, profitability, average monthly wage, and rate of job creation in 2004. Compared to the other groups, under-staffed firms fared worst in all of these performance indicators. Though understaffed, they kept losing employment and showed negative net employment change over the previous year. Over-staffed firms, on the other hand, were in slightly better economic shape and showed significant (and needed) downsizing over the previous year. The best performance in terms of labor productivity and profitability was displayed by firms with optimal staffing levels.

Table 9. Determinants of staffing: total employees (multi- nominal logit)*

\begin{tabular}{|c|c|c|c|c|c|c|}
\hline & \multicolumn{2}{|c|}{ Specification 1} & \multicolumn{2}{|c|}{ Specification 2} & \multicolumn{2}{|c|}{ Specification 3} \\
\hline & $\begin{array}{l}\text { Under- } \\
\text { staffing }\end{array}$ & $\begin{array}{c}\text { Over- } \\
\text { staffing }\end{array}$ & $\begin{array}{l}\text { Under- } \\
\text { staffing }\end{array}$ & $\begin{array}{c}\text { Over- } \\
\text { staffing }\end{array}$ & $\begin{array}{l}\text { Under- } \\
\text { staffing }\end{array}$ & $\begin{array}{c}\text { Over- } \\
\text { staffing }\end{array}$ \\
\hline Exporter & -0.303 & 0.161 & -0.225 & 0.186 & -0.241 & 0.168 \\
\hline New firm (established after 1992) & 0.097 & -0.189 & 0.098 & -0.151 & 0.077 & -0.188 \\
\hline Foreign owned & 0.076 & $0.841 * *$ & 0.033 & $0.592 *$ & 0.136 & $0.742 * *$ \\
\hline Government control (>25\%) & 0.253 & -0.077 & 0.146 & 0.051 & 0.076 & -0.157 \\
\hline Employment(log) & -0.022 & $0.460 * * *$ & 0.043 & $0.480 * * *$ & 0.038 & 0.504 \\
\hline Wages $(\log )$ & $-0.273 * *$ & -0.118 & & & & \\
\hline Value-added per worker $(\log )$ & & & $-0.281 * * *$ & $-0.226^{*}$ & & \\
\hline Profitability & & & & & $-1.080 * *$ & $-1.028 * * *$ \\
\hline Industries & Yes & Yes & Yes & Yes & Yes & Yes \\
\hline Regions & Yes & Yes & Yes & Yes & Yes & Yes \\
\hline Constant & -0.336 & -26.983 & 0.348 & -26.142 & -1.023 & -27.476 \\
\hline Pseudo-R2 & \multicolumn{2}{|c|}{$\frac{1}{0.1437}$} & \multicolumn{2}{|c|}{$\frac{1}{0.1344}$} & \multicolumn{2}{|c|}{$\frac{1}{0.1392}$} \\
\hline $\mathrm{N}$ & \multicolumn{2}{|c|}{894} & \multicolumn{2}{|c|}{929} & \multicolumn{2}{|c|}{946} \\
\hline
\end{tabular}

* In tables 9-11 the reference group is enterprises with optimal staffing.

The association between the incidence of labor shortage and economic underperformance is further analyzed in Table 9. It gives estimates from a multinomial logit model where the dependent variable equals 1 if actual employment is lower than optimal and 2 if it is excessive. Optimally staffed firms are taken as the reference group. All estimates tell us the same story: all performance-related variables are negatively and significantly associated with the incidence of reporting labor shortage. At the same time, performance indicators are not associated with the incidence of reported labor surplus. Overstaffing is more likely to be a function of past employment. Due to economic reasons, less efficient firms are unable to hire as many workers as they need and to retain them; very large firms are unable to downsize ("to lose extra weight") 
quickly regardless of their economic performance. This extra weight was inherited from the Soviet past and did not emerge from current performance. Getting rid of this "heritage" is constrained by current employment protection legislation. ${ }^{16}$

Tables 10-12 present the estimation results of a multinomial logit model for professionals and skilled workers, for which the proportion of sub-optimally staffed firms is especially large, and for unskilled workers.

Table 10. Determinants of staffing: professionals (multi-nominal logit)*

\begin{tabular}{|l|c|c|c|c|c|c|}
\hline \multirow{2}{*}{} & \multicolumn{2}{|c|}{ Specification 1 } & \multicolumn{2}{c|}{ Specification 2 } & \multicolumn{2}{c|}{ Specification 3 } \\
\cline { 2 - 7 } & $\begin{array}{c}\text { Under- } \\
\text { staffing }\end{array}$ & $\begin{array}{c}\text { Over- } \\
\text { staffing }\end{array}$ & $\begin{array}{c}\text { Under- } \\
\text { staffing }\end{array}$ & $\begin{array}{c}\text { Over- } \\
\text { staffing }\end{array}$ & $\begin{array}{c}\text { Under- } \\
\text { staffing }\end{array}$ & $\begin{array}{c}\text { Over- } \\
\text { staffing }\end{array}$ \\
\hline Exporter & $0.369^{*}$ & 0.285 & $0.491^{* *}$ & 0.350 & $0.396^{*}$ & 0.407 \\
New firm (established after 1992) & 0.145 & $-0.918^{* *}$ & -0.089 & $-0.780^{*}$ & -0.067 & $-0.958^{* *}$ \\
Foreign owned & -0.216 & 0.568 & -0.044 & 0.560 & -0.088 & 0.601 \\
Government control (>25\%) & 0.161 & -0.115 & 0.168 & 0.013 & 0.157 & -0.287 \\
Employment(log) & -0.012 & $0.637 * * *$ & 0.001 & $0.619 * * *$ & -0.016 & $0.621^{* * *}$ \\
Wages (log) & $-0.213^{*}$ & -0.042 & & & & \\
Value-added per worker (log) & & & -0.012 & -0.213 & & \\
Profitability & & & & & 0.248 & $-2.135^{* *}$ \\
Industries & Yes & Yes & Yes & Yes & Yes & Yes \\
Regions & Yes & Yes & Yes & Yes & Yes & Yes \\
Constant & $-1.622^{*}$ & $-30.27^{* * *}$ & $-2.071 * *$ & $-29.21 * * *$ & $-2.091 * *$ & $-31.20^{* * *}$ \\
\hline Pseudo-R2 & \multicolumn{2}{|c|}{0.1347} & \multicolumn{2}{|c|}{0.123} & \multicolumn{2}{c|}{0.1291} \\
\hline $\mathrm{N}$ & \multicolumn{2}{|c|}{890} & \multicolumn{2}{|c|}{925} & \multicolumn{2}{c|}{940} \\
\hline
\end{tabular}

Table 11. Determinants of staffing: skilled blue-collar workers (multi-nominal logit)*

\begin{tabular}{|l|c|c|c|c|c|c|}
\hline \multirow{2}{*}{} & \multicolumn{2}{|c|}{ Specification 1 } & \multicolumn{2}{c|}{ Specification 2 } & \multicolumn{2}{c|}{ Specification 3 } \\
\cline { 2 - 7 } & $\begin{array}{c}\text { Under- } \\
\text { staffing }\end{array}$ & $\begin{array}{c}\text { Over- } \\
\text { staffing }\end{array}$ & $\begin{array}{c}\text { Under- } \\
\text { staffing }\end{array}$ & $\begin{array}{c}\text { Over- } \\
\text { staffing }\end{array}$ & $\begin{array}{c}\text { Under- } \\
\text { staffing }\end{array}$ & $\begin{array}{c}\text { Over- } \\
\text { staffing }\end{array}$ \\
\hline Exporter & -0.022 & 0.013 & 0.054 & 0.155 & 0.024 & 0.380 \\
New firm (established after 1992) & -0.285 & 0.251 & $-0.336^{*}$ & 0.269 & $-0.387^{* *}$ & -0.004 \\
Foreign owned & 0.060 & 0.484 & 0.039 & 0.077 & -0.026 & 0.428 \\
Government control (>25\%) & -0.051 & -0.050 & -0.037 & 0.081 & -0.050 & -0.225 \\
Employment(log) & $0.181^{*}$ & 0.359 & $0.167^{*}$ & 0.306 & 0.138 & 0.337 \\
Wages (log) & $-0.323^{* * *}$ & -0.319 & & & & \\
Value-added per worker (log) & & & $-0.303^{* * *}$ & -0.314 & & \\
Profitability & & & & & -0.419 & -0.462 \\
Industries & Yes & Yes & Yes & Yes & Yes & Yes \\
Regions & Yes & Yes & Yes & Yes & Yes & Yes \\
Constant & $-1.37^{*}$ & -26.06 & -0.190 & -24.63 & $-1.65^{* *}$ & -43.04 \\
\hline Pseudo-R2 & \multicolumn{2}{|c|}{0.1455} & \multicolumn{2}{|c|}{0.1378} & \multicolumn{2}{c|}{0.1352} \\
\hline N & \multicolumn{2}{|c|}{890} & \multicolumn{2}{|c|}{941} \\
\hline
\end{tabular}

\footnotetext{
${ }^{16}$ Association between the EPL and labor market behavior of firms is discussed in Section 6 of this paper.
} 
Table 12. Determinants of staffing: unskilled workers (multi-nominal logit)*

\begin{tabular}{|c|c|c|c|c|c|c|}
\hline & \multicolumn{2}{|c|}{ Specification 1} & \multicolumn{2}{|c|}{ Specification 2} & \multicolumn{2}{|c|}{ Specification 3} \\
\hline & $\begin{array}{l}\text { Under- } \\
\text { staffing }\end{array}$ & $\begin{array}{l}\text { Over- } \\
\text { staffing }\end{array}$ & $\begin{array}{l}\text { Under- } \\
\text { staffing }\end{array}$ & $\begin{array}{l}\text { Over- } \\
\text { staffing }\end{array}$ & $\begin{array}{l}\text { Under- } \\
\text { staffing }\end{array}$ & $\begin{array}{l}\text { Over- } \\
\text { staffing }\end{array}$ \\
\hline Exporter & 0.265 & -0.012 & 0.251 & 0.068 & 0.343 & 0.107 \\
\hline New firm (established after 1992) & -0.025 & -0.305 & -0.192 & -0.269 & -0.015 & -0.378 \\
\hline Foreign owned & 0.457 & $1.063 * * *$ & 0.385 & $0.998 * * *$ & 0.303 & $0.951 * * *$ \\
\hline Government control (>25\%) & 0.043 & -0.334 & 0.023 & -0.371 & 0.002 & -0.394 \\
\hline Employment(log) & 0.130 & $0.479 * * *$ & 0.151 & $0.425 * * *$ & 0.165 & $0.426 * * *$ \\
\hline Wages $(\log )$ & -0.082 & -0.118 & & & & \\
\hline Value-added per worker (log) & & & $-0.204 *$ & 0.027 & & \\
\hline Profitability & & & & & $-1.432 * *$ & -0.283 \\
\hline Industries & Yes & Yes & Yes & Yes & Yes & Yes \\
\hline Regions & Yes & Yes & Yes & Yes & Yes & Yes \\
\hline Constant & $-3.57 * * *$ & $-28.85 * * *$ & $-2.57 * *$ & $-29.23 * * *$ & $-3.70 * * *$ & $-29.18^{* * *}$ \\
\hline$\overline{\text { Pseudo-R2 }}$ & \multicolumn{2}{|c|}{0.1425} & \multicolumn{2}{|c|}{0.1347} & \multicolumn{2}{|c|}{0.1358} \\
\hline $\mathrm{N}$ & \multicolumn{2}{|c|}{847} & \multicolumn{2}{|c|}{879} & \multicolumn{2}{|c|}{898} \\
\hline
\end{tabular}

Firms with low productivity tend to have a higher incidence of claims of a shortage of skilled workers but not of professionals. Meanwhile, profitability has no statistically meaningful effect on the likelihood of a shortage of these groups. Ceteris paribus, exporters need more professionals, and firms founded prior to 1992 claim that they need additional manual skilled workers. The incidence of a shortage of unskilled labor does not depend on the structural characteristics of firms, but it is negatively related to profitability and productivity. The effect of average wage is statistically insignificant in this case.

We now consider the factors affecting the incidence of labor surplus. For professionals, two factors are significant in all specifications: the age and size of the firms. Old (established prior to 1992) and large firms have a higher probability to need a downsizing of professionals. Firms that claim to have a surplus of skilled manual workers do not differ much from those with optimal employment. However, this could be due to the fact that the first group makes up a very small portion of the sample (4.2 percent). Large firms and firms with foreign ownership are more likely to have unskilled workers in excess. Though seems strange, the latter can be due to the fact that the presence of a foreign investor strengthens efficiency, enhancing pressure on management; this pressure may result in a more intense restructuring accompanied by a downsizing of unskilled labor (see Table 5).

Production functions with alternative specifications summarize the results. In addition to capital (log), employment (log), and total number of years of schooling as independent variables, we used dummy variables to indicate whether a firm has optimal employment (the base category), or a surplus or a shortage of manpower. The first specification included dummies for shortage/excess in relation to all employees, and other specifications differentiated 
shortage/surplus by skill groups (managers, professionals, clerks, skilled and unskilled workers). The log value added was on the left hand side of the model.

As Table 13 suggests, suboptimal employment is more frequent and more acute for economically inefficient enterprises. In fact, there is a strong and negative association between the incidence of shortage/surplus and the performance of the firm. In the version of a CobbDouglas production function with general staffing variables, the regression coefficient for the labor shortage dummy turns out to be significant at the 1 percent level and the coefficient for the labor surplus dummy is significant at the 5 percent level. The estimates allow us to conclude that, ceterus paribus, under-staffed firms have a TFP lower by 7.5 percent as compared to firms that report optimal level of employment, and the TFP of over-staffed ones is lower by 6 percent. ${ }^{17}$ This adds econometric evidence to the fact that the least efficient and competitive firms are the most exposed to a shortage or surplus of labor. Though some endogeneity between productivity and the incidence of non-optimal employment cannot be excluded, these estimates capture the fact that they go together.

Table 13. Productivity and optimality of staffing (augmented Cobb-Douglass production function)

\begin{tabular}{|l|c|c|c|c|c|c|}
\hline Dependent var.: log VA & $\begin{array}{c}\text { All } \\
\text { employees }\end{array}$ & Managers & $\begin{array}{c}\text { Profes- } \\
\text { sionals }\end{array}$ & Clerks & $\begin{array}{c}\text { Skilled } \\
\text { workers }\end{array}$ & $\begin{array}{c}\text { Unskilled } \\
\text { workers }\end{array}$ \\
\hline Capital (Log) & $0.246^{* * *}$ & $0.258^{* * *}$ & $0.261^{* * *}$ & $0.261^{* * *}$ & $0.248^{* * *}$ & $0.260^{* * *}$ \\
Labor (Log) & $0.886^{* * *}$ & $0.867^{* * *}$ & $0.859^{* * *}$ & $0.861^{* * *}$ & $0.881^{* * *}$ & $0.877 * * *$ \\
Average years of & $0.001^{* * *}$ & $0.001^{* * *}$ & $0.001^{* * *}$ & $0.001^{* * *}$ & $0.001^{* * *}$ & $0.001^{* * *}$ \\
schooling & & & & & & \\
Staffing (optimal) & & & & & \\
$\quad$ Under-staffing & $-0.404^{* * *}$ & -0.190 & 0.000 & -0.039 & $-0.344^{* * *}$ & $-0.390^{* * *}$ \\
$\quad$ Over-staffing & $-0.331^{* *}$ & -0.272 & -0.130 & -0.216 & -0.258 & -0.185 \\
Missing values & Yes & Yes & Yes & Yes & Yes & Yes \\
Regions & Yes & Yes & Yes & Yes & Yes & Yes \\
\hline Constant & $5.485^{* * *}$ & $5.178^{* * *}$ & $5.137^{* * *}$ & $5.142^{* * *}$ & $5.410^{* * *}$ & $5.205^{* * *}$ \\
\hline $\mathrm{N}$ & 657 & 657 & 657 & 657 & 657 & 657 \\
\hline $\mathrm{R}^{2}$ & 0.59 & 0.58 & 0.58 & 0.58 & 0.59 & 0.59 \\
\hline
\end{tabular}

* Significant at $10 \% * *$ Significant at $5 \% ; * * *$ Significant at $1 \%$

The versions of production function that include variables related to staffing levels in particular occupational groups show that neither a surplus nor a shortage of white collar workers (managers, professionals, clerks) affects firm performance. Nevertheless, it is worth noting that all of them have the expected negative sign. However, the impact of skilled blue collar workers is statistically significant. Firms reporting a shortage of skilled workers have a TFP 6.5 percent lower than firms with the desired number of such workers. More surprising is the fact that they

17 These estimates are very approximate since they are based on the simplest Cobb-Douglas production function. 
display the same pattern (of negative and significant association) for a shortage of unskilled workers. Measures of a surplus of skilled as well as unskilled workers show a weak association with firm performance.

In sum, all the available evidence tells the same story. A surplus or shortage of labor, as they are reported by firms, reflect their inability to offer competitive wages in order to attract and retain workers of the required quantity and skills. If this conclusion is correct, then the main problem is seen not in the numerical deficit of workers, including skilled workers, but in the inefficiency of the general market selection mechanism. This inefficiency allows unviable Russian industrial firms to stay afloat and loudly call for more workers.

\section{How should the shortage be rectified?}

Firms that report a shortage of labor can search for a remedy in several complementary ways. These include: searching for additional workers in the external market, increasing the number of working hours for existing personnel, investing in productivity-enhancing on-the-job training of workers.

The first and most obvious way for overcoming the shortage is to intensify recruitment activities. It is reasonable to expect that firms experiencing a labor shortage should lead in job creation and lag in job destruction. However, the actual picture appears to be the opposite (Table 14). In 2004, understaffed firms gained 3 percent of new jobs and lost 6 percent of old ones. They created new jobs almost at the same rate as optimally staffed firms did, and they lost jobs at the same rate as overstaffed ones. Their main problem that emerged here was their inability to retain current jobs and workers. They also faced difficulties in hiring new employees.

Table 14. Job creation and job destruction by levels of staffing, 2004, percent*

\begin{tabular}{|l|c|c|c|c|}
\hline Staffing Level & $\begin{array}{c}\text { Proportion of firms } \\
\text { creating jobs }\end{array}$ & $\begin{array}{c}\text { Proportion of firms } \\
\text { destroying jobs }\end{array}$ & Job creation rate & Job destruction rate \\
\hline Optimal & 54.6 & 45.4 & 3.2 & 4.7 \\
Under-staffed & 49.6 & 50.4 & 3.1 & 6.1 \\
Over-staffed & 39.7 & 60.3 & 1.8 & 6.5 \\
\hline Total & 51.3 & 48.7 & 2.9 & 5.3 \\
\hline
\end{tabular}

* In estimating JC and JD rates, we excluded $1 \%$ of firms with maximum job losses and $1 \%$ of firms with maximum job gains.

Table 15 reports managers' estimates of the difficulties in searching for and hiring new workers from various occupational groups. The most serious difficulties (the number of respondents who chose "very serious problems" or "problems cannot be solved within acceptable time periods") arise when firms search for skilled manual workers. Around 37 percent of respondents reported very serious difficulties. (Note that although about 50 percent of surveyed firms reported a shortage of skilled workers, a much smaller proportion of them 
recognized serious difficulties in searching or hiring!) This proportion does not depend on firm size, age, or dynamics of employment, but it is higher for state-owned firms, among which every second firm reports critical difficulties.

Table 15. Difficulties in searching and hiring workers, by major occupational groups, $\%$

\begin{tabular}{|l|c|c|c|c|c|}
\hline $\begin{array}{c}\text { Hiring from skill } \\
\text { groups }\end{array}$ & $\begin{array}{c}\text { No } \\
\text { difficulties }\end{array}$ & $\begin{array}{c}\text { Some } \\
\text { difficulties } \\
\text { arise but not } \\
\text { often }\end{array}$ & $\begin{array}{c}\text { Difficulties arise } \\
\text { frequently but they } \\
\text { are solved within } \\
\text { short periods of } \\
\text { time }\end{array}$ & $\begin{array}{c}\text { Very serious } \\
\text { difficulties }\end{array}$ & $\begin{array}{c}\text { Difficulties } \\
\text { cannot be } \\
\text { solved within } \\
\text { acceptable time } \\
\text { periods }\end{array}$ \\
\hline Managers & 43.6 & 27.5 & 14.1 & 13.4 & 1.2 \\
Professionals & 34.2 & 29.1 & 22.5 & 13.2 & 0.9 \\
Clerks & 79.8 & 12.5 & 5.1 & 2.5 & 0 \\
Skilled workers & 15.0 & 19.0 & 28.6 & 33.5 & 3.4 \\
Unskilled workers & 67.4 & 13.6 & 10.9 & 4.8 & 0.5 \\
\hline
\end{tabular}

Similar estimates for managers and professionals are around 15 percent. For professionals this estimate is about the same for all groups of firms. For managers, it reaches 25 percent for the largest firms in our sample, around 33 percent for firms established after 1965 and 20 percent for firms creating new jobs. Not surprisingly, searching for and clerks and unskilled workers is the easiest, and 84-92 percent managers reported either no difficulties with searching and hiring at all, or only episodic difficulties.

Table 16. Distribution of enterprises under-staffed with various skill groups, by degrees of difficulty in searching for and hiring various skill groups, percent

\begin{tabular}{|l|c|c|c|c|c|c|}
\hline $\begin{array}{c}\text { Firms with an } \\
\text { understaffing of... }\end{array}$ & $\begin{array}{c}\text { No } \\
\text { difficulties }\end{array}$ & $\begin{array}{c}\text { Some } \\
\text { difficulties } \\
\text { arise but not } \\
\text { often }\end{array}$ & $\begin{array}{c}\text { Difficulties arise } \\
\text { frequently but } \\
\text { they are solved } \\
\text { within short } \\
\text { periods of time }\end{array}$ & $\begin{array}{c}\text { Very } \\
\text { serious } \\
\text { difficulties }\end{array}$ & $\begin{array}{c}\text { Difficulties } \\
\text { cannot be } \\
\text { solved within } \\
\text { acceptable } \\
\text { time periods }\end{array}$ & $\begin{array}{c}\text { Integral } \\
\text { index, } \\
\text { scores }\end{array}$ \\
\hline Managers & 57.1 & 15.4 & 18.1 & 8.5 & 0.8 & 1.8 \\
Professionals & 4.2 & 24.3 & 33.3 & 35.4 & 2.6 & 3.1 \\
Clerks & 36.8 & 15.8 & 31.6 & 15.8 & 0.0 & 2.3 \\
Skilled workers & 1.5 & 10.3 & 31.3 & 51.7 & 5.2 & 3.5 \\
Unskilled workers & 7.8 & 23.3 & 43.1 & 24.1 & 1.7 & 2.9 \\
\hline
\end{tabular}

How do complaints of a shortage of labor in particular occupational groups relate to actual difficulties in searching and hiring? Table 16 suggests that this association appears to be quite weak in most cases. Only 10 percent of firms reporting a shortage of managers faced actual difficulties in searching for managers. For clerks, this indicator is under 20 percent; for unskilled workers, it was slightly above 25 percent. For professionals and skilled workers only, it reached worrisome percentages of 40 and 60, respectively. But even these estimates suggest that about half of the firms reporting a shortage of skilled labor find the employees they need without serious difficulties. 
An alternative strategy to remedy a labor shortage is to extend working hours and optimize the utilization of working time. However, as Table 17 shows, under-staffed firms had the largest losses of working time. Their losses made up 16 percent of their annual amount of working hours, against 12-13 percent reported by optimally staffed or over-staffed firms. Additional vacations, absences, and sick leaves were among the main reasons for underutilization of working time. This raises the question of whether the labor shortage claimed by these firms emerges as a consequence of their own inability to efficiently utilize their existing workforce. In any case, under-staffed firms behave in a far different way than one would expect. Instead of making working hours longer, these firms tend to have (or force?) their employees to work even shorter hours.

Table 17. Losses of working time by levels of staffing (percent of the total annual number of working hours)

\begin{tabular}{|l|c|c|c|c|c|c|}
\hline \multirow{2}{*}{ Staffing Level } & \multicolumn{5}{|c|}{ Losses of working time by main reasons } \\
\cline { 2 - 7 } & Strikes & $\begin{array}{c}\text { Additional leaves } \\
\text { by workers' } \\
\text { initiative }\end{array}$ & $\begin{array}{c}\text { Sick } \\
\text { leaves }\end{array}$ & $\begin{array}{c}\text { Leaves by } \\
\text { employers' } \\
\text { initiative }\end{array}$ & Absenteeism & Total \\
\hline Optimal & 0.4 & 3.2 & 6.8 & 1.2 & 0.7 & 12.3 \\
Under-staffed & 0.1 & 3.8 & 8.5 & 2.4 & 1.4 & 16.2 \\
Over-staffed & 0.0 & 2.6 & 7.0 & 2.7 & 0.9 & 13.2 \\
\hline Total & 0.2 & 3.3 & 7.3 & 1.8 & 0.9 & 13.5 \\
\hline
\end{tabular}

One possible solution to skill shortages in the local labor market is to train or upgrade the skills of the existing workforce ${ }^{18}$. Investments in in-service training are an important precondition of competitiveness. ${ }^{19}$ They build special skills and knowledge that are complementary to technology. Correspondingly, one could expect that firms with a labor shortage tend to invest more in in-service training. Is this strategy used by such firms?

18 The hiring versus retraining option is discussed by Denisova (2005), based upon a survey of 1,000 industrial enterprises in 2004. In her survey, 56 percent of firms noted that retraining existing workers is the most efficient way to meet skill shortages, 35 percent state that hiring from the external market is preferable, and 25 percent prefer cooperation with education and training institutions to provide trained personnel. See: Lazareva O., Denisova I., and S. Tsuhlo. Hiring or Retraining: the Russian Firms' Experience. Working paper WP3/2006/11. Moscow: Higher School of Economics (in Russian).

${ }^{19}$ O. Lazareva et al. Op. cit.; «Building Skills and Absorptive Capacity in Russian Enterprises: Competitiveness and Investment Climate Assessment for the Russian Federation», World Bank, 2007. 
Simple tabulations suggest that about 70 percent of manufacturing enterprises in the sample provide employees with in-service training. If compared to training incidence in other BRIC countries, Russia trails behind China and Brazil, though it is far ahead of India.

However, these simple estimates of training incidence are misleading because Russian firms that report training actually provide training to very few of their employees. Conditional on the firm providing training, the survey suggests that managers, professionals and skilled workers are the three skill groups most likely to benefit from in-service training. On average, only 9-10 percent of managers and professionals and about 7-8 percent of skilled workers receive formal training. These figures seem to be extremely low by international comparisons, and suggest that in-service training practices are not firmly entrenched among Russian firms. ${ }^{20}$ Thus, while many more Russian firms train, they provide training to a relatively small percent of their workforce as compared to other countries. Another important finding is that on average formal in-service training provided by the Russian enterprises is rather short - no more than two-three weeks.

Are firms that report under-staffing more likely to train workers in order to meet skill shortfalls? We might expect the answer to be positive, yet surprisingly it is not. As Table 18 shows, 67-69 percent of firms with a labor shortage train their workers, and this does not differ from training in optimally staffed firms. In fact, firms that identified themselves as being overstaffed were more likely than other firms (those with optimal staffing or under-staffing) to provide in-service training. Among them, 84 percent reported that they trained their personnel. These firms were also more active in in-house training of particular occupational groups. One explanation, consistent with Table 5, is that skill shortages in specific skill groups can co-exist with overall optimal or over-staffing, so even over-staffed firms train. Another explanation is that this group consists of large firms, many of which have their own in-house training institutions and programs. Large firms can also benefit from economies of scale, since training costs per worker will be lower than for smaller enterprises. Compared to the two other groups of firms, firms with a labor shortage did more training for unskilled workers and less for managers and skilled workers.

20 In Malaysia, a rapidly growing East Asian country, a World Bank study (1997) that also ranked skill shortages estimated that 24 percent of managers, 32 percent of professionals and technicians, and between 13 and 16 percent of production workers received formal in-service training. See World Bank (2004), "Malaysia: Firm Competitiveness, Investment Climate and Growth". 
However, the duration of training was longest at under-staffed firms and was 4 weeks on average, against 2-3 weeks at other firms. This could be due to the fact that these firms were only able to attract a lower quality labor force that needed longer training even for basic tasks.

At all firms regardless of their staffing (surplus/optimal/shortage), there were inconsistencies between demand for skills and in-firm training. As Table 18 suggests, managers and professionals were trained most frequently, though the shortage of these workers was not the most acute. However, the priority of these groups is easily explained, since investments in their specific human capital can bring higher returns than investments in blue-collar workers or clerks. Interestingly, though complaints of understaffed firms of a shortage of skilled manual workers are almost universal (97 percent), they do not lead to more investments in training this group of workers. Only one third of these firms invested in the in-firm training of skilled workers.

Table 18. In-service training by staffing levels

\begin{tabular}{|c|c|c|c|}
\hline & $\begin{array}{l}\text { Proportion of enterprises } \\
\text { providing any in-firm } \\
\text { training, per cent }\end{array}$ & $\begin{array}{l}\text { Proportion of employees } \\
\text { trained over the year, } \\
\text { percent (conditional on the } \\
\text { provision of in-firm } \\
\text { training) }\end{array}$ & $\begin{array}{c}\text { Average duration of in-firm } \\
\text { training in weeks } \\
\text { (conditional on the } \\
\text { provision of in-firm } \\
\text { training) }\end{array}$ \\
\hline & \multicolumn{3}{|c|}{ Enterprises with optimal staffing } \\
\hline Total employees & 67.2 & - & - \\
\hline Managers & 40.5 & 8.8 & 2.7 \\
\hline Professionals & 41.0 & 9.0 & 3.2 \\
\hline Clerks & 14.9 & 1.0 & 2.2 \\
\hline Skilled workers & 34.8 & 8.0 & 3.6 \\
\hline \multirow[t]{2}{*}{ Unskilled workers } & 12.8 & 1.2 & 2.9 \\
\hline & \multicolumn{3}{|c|}{ Under-staffed enterprises } \\
\hline Total employees & 68.9 & - & - \\
\hline Managers & 41.1 & 7.5 & 3.1 \\
\hline Professionals & 47.0 & 9.4 & 3.3 \\
\hline Clerks & 11.9 & 1.3 & 1.8 \\
\hline Skilled workers & 34.1 & 5.7 & 3.7 \\
\hline \multirow[t]{2}{*}{ Unskilled workers } & 13.7 & 1.8 & 4.1 \\
\hline & \multicolumn{3}{|c|}{ Over-staffed enterprises } \\
\hline Total employees & 84.1 & - & - \\
\hline Managers & 54.7 & 11.0 & 2.7 \\
\hline Professionals & 62.5 & 13.5 & 2.2 \\
\hline Clerks & 18.8 & 1.1 & 1.5 \\
\hline Skilled workers & 39.8 & 7.8 & 2.8 \\
\hline Unskilled workers & 16.4 & 1.1 & 2.1 \\
\hline
\end{tabular}

So why do Russian firms not train in-house to meet skill shortfalls? The importance of various training correlates can be investigated within a regression framework using a probit model. The model estimates the probability of in-service training by regressing the "any formal training" variable on a set of explanatory variables, including measures of firm size, the share of workers with higher education, and other firm attributes such as export orientation, R\&D 
spending and foreign or government ownership. A corresponding set of regressions were estimated separately for the probability of in-house training and external training.

Table 19. Determinants of in-service training and training by source (probit models, marginal effects)

\begin{tabular}{|c|c|c|c|}
\hline Dependent variable: dummy for training & Any training & In-house training & External training \\
\hline$\%$ workers with higher education & 0.002 & 0.000 & $0.002 *$ \\
\hline Positive R\&D spending & 0.052 & $0.066^{*}$ & 0.047 \\
\hline New firm (established after 1992) & -0.021 & 0.004 & -0.058 \\
\hline Exporter & $0.067 *$ & $0.079 * *$ & $0.078 * *$ \\
\hline Some foreign ownership & -0.072 & -0.033 & $-0.092 *$ \\
\hline Government control (>25\%) & 0.056 & 0.002 & $0.116 * *$ \\
\hline \multicolumn{4}{|l|}{ Firm size dummies (less than 250) } \\
\hline $251-500$ & $0.113 * * *$ & $0.089^{* *}$ & $0.124 * * *$ \\
\hline $501-1000$ & $0.168 * * *$ & $0.174 * * *$ & $0.216 * * *$ \\
\hline More than 1000 & $0.215 * * *$ & $0.314 * * *$ & $0.269 * * *$ \\
\hline \multicolumn{4}{|l|}{ Staffing level (optimal) } \\
\hline Under-staffed & 0.053 & $0.073^{*}$ & 0.031 \\
\hline Over-staffed & $0.133 * * *$ & $0.138 * *$ & $0.124 * *$ \\
\hline Industries & Yes & Yes & Yes \\
\hline Regions & Yes & Yes & Yes \\
\hline Missing values & Yes & Yes & Yes \\
\hline $\mathrm{N}$ & 964 & 969 & 963 \\
\hline Pseudo R2 & 0.1464 & 0.1390 & 0.1396 \\
\hline
\end{tabular}

The regression results reported in Table 19 confirm the importance of several factors that shape the demand for in-service training provision. First, the likelihood of in-service training is higher in larger firms (those with over 250 employees). Second, export-oriented firms and, to a lesser extent, firms that engage in $\mathrm{R} \& \mathrm{D}$, are also more likely to train. Employers that export have greater incentives to train their workers to produce high quality products meeting the exacting standards of foreign buyers, and to increase labor productivity to meet competitive pressures (Tan and Batra 1995; Batra and Stone 2004).

The second and third columns of Table 19 highlight differences in the determinants of external and in-house training. Training from external sources tend to be more common among firms where the government has controlling interests, and in export-oriented firms with a high share of highly educated workers. This reliance on external training appears to be a carry-over from the pre-transition period, when many state-owned enterprises had arrangements to hire specifically-trained graduates from related vocational and technical training institutions. By contrast, in-house training is shaped less by the share of highly educated workers, and more by the firm's export orientation and R\&D spending.

As far as shortage/surplus variables are concerned, a labor shortage seems to stimulate inhouse training but has little impact on provision of more expensive external training. In addition, any external training provides general skills and knowledge which are portable and can be used 
outside the firm. Expectations that trained workers may behave opportunistically may destimulate investments in external training. Ceteris paribus, over-staffed firms provided some training 13-15 percent more frequently than firms that were optimally staffed. This confirms the conclusion made earlier that a general surplus does not exclude a shortage of specific skills and experience. There are different sources of demand for training, not just for making up numerical labor shortfalls, but also for meeting the specific skill needs for exporting and new technology, as suggested by Table 19 .

Table 20. Determinants of in-service training for various skill groups (probit models, marginal effects)

\begin{tabular}{|c|c|c|c|c|c|}
\hline & Managers & Professionals & Clerks & $\begin{array}{c}\text { Skilled } \\
\text { workers }\end{array}$ & $\begin{array}{c}\text { Unskilled } \\
\text { workers }\end{array}$ \\
\hline Positive R\&D spending & $0.088 * *$ & $0.065 *$ & $0.054 *$ & -0.010 & 0.010 \\
\hline $\begin{array}{l}\text { New firm (established after } \\
\text { 1992) }\end{array}$ & -0.010 & -0.023 & 0.011 & -0.014 & -0.019 \\
\hline Exporter & 0.045 & 0.041 & -0.014 & 0.032 & 0.007 \\
\hline Some foreign ownership & 0.020 & 0.005 & -0.005 & -0.030 & 0.007 \\
\hline Government control (>25\%) & 0.044 & -0.036 & 0.032 & 0.008 & 0.046 \\
\hline \multicolumn{6}{|l|}{$\begin{array}{l}\text { Firm size dummies (less than } \\
250 \text { ) }\end{array}$} \\
\hline $251-500$ & $0.099 * *$ & $0.127 * * *$ & 0.030 & $0.080^{*}$ & $0.083^{* * *}$ \\
\hline $501-1000$ & $0.247 * * *$ & $0.195 * * *$ & -0.022 & $0.139 * * *$ & 0.024 \\
\hline More than 1000 & $0.224 * * *$ & $0.205 * * *$ & $0.085^{* *}$ & $0.196 * * *$ & $0.118^{* * *}$ \\
\hline \multicolumn{6}{|l|}{ Staffing level (optimal) } \\
\hline Under-staffed & -0.050 & -0.007 & --- & -0.016 & -0.001 \\
\hline Over-staffed & 0.045 & $0.200 * * *$ & 0.045 & 0.076 & 0.000 \\
\hline \multicolumn{6}{|c|}{ Degrees of difficulty searching for and hiring different skill groups (no difficulties) } \\
\hline $\begin{array}{r}\text { Some difficulties, or difficulties } \\
\text { are solved within short periods } \\
\text { of time }\end{array}$ & 0.037 & -0.002 & $0.093 * * *$ & $0.097 *$ & 0.009 \\
\hline $\begin{array}{r}\text { Very serious or unsolvable } \\
\text { difficulties }\end{array}$ & $0.128 * *$ & $0.122^{* *}$ & -0.024 & $0.109 *$ & 0.052 \\
\hline Industries & Yes & Yes & Yes & Yes & Yes \\
\hline Regions & Yes & Yes & Yes & Yes & Yes \\
\hline Missing values & Yes & Yes & Yes & Yes & Yes \\
\hline $\mathrm{N}$ & 982 & 980 & 873 & 982 & 827 \\
\hline Pseudo R2 & 0.1056 & 0.1012 & 0.0938 & 0.1046 & 0.0979 \\
\hline
\end{tabular}

Table 20 analyzes how firms use training to overcome labor shortages for particular occupational groups. Larger firms train more in all occupational groups and benefit from economies of scale. Innovative firms are more likely to train, but white-collar workers only. However, there are no visible effects of staffing variables on the training activities of particular occupational groups. The only relevant finding is that training is more common at over-staffed firms. Another interesting tendency is that high search and hiring costs emerge here as a main stimulus to provide training. This effect $\dot{s}$ statistically significant for all occupational groups except unskilled workers. However, in any case it can be argued that under-staffed firms are not 
more likely to invest in firm-specific skills than optimally staffed or over-staffed firms. This questions the hypothesis that employers' claims of a shortage of labor or particular skills provide reliable signals.

As a preliminary conclusion, it seems that firms that claim to experience a labor shortage do little of what might be expected given a physical lack of the requisite workforce. They do little to minimize the losses of working time or to have employees work more hours, they invest less in training, and they are rather passive in hiring. This bundle of behavioral responses complements the image of these firms as market losers (non-competitive in the labor market).

\section{Non-optimal Employment and EPL Stringency}

Russian enterprises may also be constrained from meeting reported skill shortages by employment protection legislation (EPL). There is an emerging literature suggesting that overly strict EPL can negatively affect hiring and firing, stifle job creation and lead to higher unemployment. Labor legislation (regarding minimum wages, social benefits and guarantees, employment contracts, and layoff regulations) can change labor costs for employers and, if strictly enforced, weakens incentives to hire new workers or discharge redundant ones even when warranted by labor demand. Hence, non-optimal employment can persist if labor turnover costs are prohibitively high. Firing costs incurred by EPL slow adjustment. ${ }^{21}$ Firing excess workers may cost too much and take too much time, thus inducing employers to keep excess labor or press workers to quit voluntarily. Firing costs become hiring costs since employers cannot exclude falling demand in the future.

In the IC survey, respondents reported on various constraints that hindered enterprise activity and also evaluated the relative importance of these constraints by using a 5-score scale. Only around 5 percent of respondents recognized the current "regulations of industrial relations" regime as a serious or very serious constraint on production. Adding those who consider these regulations to be a significant constraint makes up around 17 percent of all firms surveyed. Compared to other constraints, this does not seem to be a real barrier. The results vary little across the major groups of firms, and this seems to confirm that the EPL stringency is not a serious issue. However, this conclusion is premature.

First, this negative rating of IC barriers is led by a few general characteristics of the economic environment and regulations for which the "regulations of industrial relations" emerge as a particular case. Second, "the regulations of industrial relations" may be considered by top-

${ }^{21}$ See, for example, the excellent survey by J. Addison and P. Teixeira, "The Economics of Employment Protection”. IZA, DP 381, October 2001. 
managers to be collective bargaining procedures or relationships with unions, which are not in fact a constraint. Third, a shortage of skilled labor is considered generally to be a serious constraint, and this, its turn, may be associated with the regulations of industrial relations.

We study the impact of labor regulations on economic activity in more detail using the question about what EPL rules and procedures create the most serious difficulties (Table 21).

Table 21. Distribution of surveyed enterprises by answers to the question "Which labor regulations create major problems for your enterprises?", percent

\begin{tabular}{|l|c|c|c|c|}
\hline \multirow{2}{*}{ Labor regulations } & \multirow{2}{*}{ Total } & \multicolumn{3}{|c|}{ Staffing levels } \\
\cline { 3 - 5 } & & Under-staffed & Optimal & Over-staffed \\
\hline Hiring and firing rules & 18,8 & 15,9 & 18,2 & 25,8 \\
Use of short-term contracts & 11,8 & 10,4 & 12,3 & 11,7 \\
Working time regulations & 15,3 & 13,7 & 15,5 & 17,2 \\
Minimum wage rules & 10,6 & 13,0 & 10,0 & 10,9 \\
Social benefit provisions & 12,5 & 12,6 & 10,1 & 17,2 \\
Rules on timing of wage payments & 12,1 & 12,6 & 10,1 & 17,2 \\
Relations to TU & 4,1 & 3,0 & 4,7 & 3,9 \\
Hiring of foreign workers & 20,2 & 27,8 & 18,2 & 14,8 \\
Others & 3,1 & 3,0 & 3,0 & 3,9 \\
\hline There are no such rules & 39,7 & 35,6 & 42,6 & 37,5 \\
\hline $\mathrm{N}$ & 1002 & 592 & 270 & 128 \\
\hline
\end{tabular}

Table 21 shows that one fifth of all respondents reported that rules on hiring foreign labor created serious difficulties, 19 percent indicated hiring and firing rules and 15 percent stressed the problems that arise from working time regulations. Only 40 percent believed that labor regulations did not create any major problems for their enterprise ${ }^{22}$.

Interestingly, firms that were over-staffed tended more frequently (than other firms) to select hiring and firing rules, working time regulations, and rules on timing for wage payments as the most constraining of all labor regulations. This is understandable since exactly these firms (with excess staff) need to downsize more than others. On the other hand, firms with understaffing tend to stress minimum wage rules, and rules governing the hiring of foreign workers as creating difficult problems for them. This comes as an additional illustration for their policy towards hiring cheap and low-skilled labor.

22 There are simple and quasi-legal ways in Russia to deal with the EPL constraints and turn labor-management relations into a quasi "employment-at-will" practice. First, employers can pressure workers to quit voluntarily. Second, there are informal practices of asking workers to submit an application to quit voluntarily when first being hired. This allows managers to date the application themselves and initiate a "voluntary" quit at any time and at no costs. These and certain other informal practices can result in a high labor turnover driven by quits with almost no lay-offs. 
Labor adjustment costs induced by the EPL are likely to make it more difficult for firms to search for and hire needed skilled workers. Table 22 reports estimates from an ordered probit model in which the 5-score index of difficulty (ranking of 1 to 5 , where 5 is for the maximum difficulty) of searching for and hiring skilled labor is regressed on the index of EPL as a constraint (sum of different EPL components that respondents indicate as problematic), wage levels in the firms and other enterprise characteristics that might shape skills demand. (As independent variables, we use either an index summing up EPL stringency perceptions (columns 2 and 3 of the table) or the dummy for the position that "the EPL does not contain any rules and norms that can create additional difficulties". The model is estimated separately for professionals and for skilled workers, the two groups that are in greatest demand.

The results provide evidence that the EPL index is positively associated with the actual difficulties firms may experience in searching for and hiring professionals and skilled workers. The higher the sum of EPL rankings as a constraint, the more likely the firms are to report search and hiring difficulties for both professionals and skilled workers. Firms that are able to circumvent EPL, on the other hand, are less likely to rank searching and hiring skilled labor as a problem. The results in Table 22 also confirm that firms paying non-competitive wages are also more likely to report difficulties in searching for and hiring skilled labor. This corresponds to the conclusion made earlier that the recruitment (and hiring) and retention of skilled employees depend on demand constraints. Another interesting fact that follows from Table 22 is that small and medium sized firms (up to 250 employees) are less likely to have recruitment problems. This can be explained by the fact that the true regulatory regime for small firms is rather flexible and these firms feel the pressure from EPL relatively less.

Table 22. EPL as a constraint on hiring skilled labor (ordered probit)

\begin{tabular}{|l|c|c|c|}
\hline \multirow{2}{*}{ Dependent variable: } & \multicolumn{3}{|c|}{ Difficulty in search for and hiring labor } \\
\cline { 2 - 4 } & Professionals & $-0.199^{* * *}$ & $-0.197^{* * * *}$ \\
\hline Log(wages) & $-0.093^{*}$ & 0.021 & 0.023 \\
Government control (>25\%) & $0.218^{* *}$ & -0.036 & -0.042 \\
Some foreign owner & -0.153 & $-0.166^{* *}$ & $-0.162^{* *}$ \\
Small firm (<250 employees) & $-0.301^{* * *}$ & 0.044 & 0.033 \\
Positive R\&D spending & $0.208^{* * *}$ & -0.115 & -0.122 \\
New Firm (established after 1992) & 0.078 & $0.094^{* * *}$ & - \\
EPL index & $0.108^{* * *}$ & - & $-0.306^{* * * *}$ \\
EPL is not a constraint & - & Yes & Yes \\
Industries & Yes & Yes & Yes \\
Regions & Yes & 898 & 898 \\
\hline $\mathrm{N}$ & 896 & 181,13 & 189,56 \\
\hline LR chi2 & 123,85 & $\%$, & 5 \\
\hline
\end{tabular}

Note: Zvalues in parentheses and * statistically significant at $10 \%$, ** significant at $5 \%$ and *** significant at $1 \%$. EPL index is the sum of rankings for EPL related difficulties. 


\section{Conclusions}

During the 1990s, many observers of the Russian labor market highlighted the issue of widespread under-employment, hidden unemployment, and underutilization of labor. The economic growth and recovery in the 2000s brought the opposite conviction that a shortage of labor and skills had emerged as a crucial constraint for growth. This conviction strengthened over time and by 2005-2006 had become a consensus. For many Russian politicians, bureaucrats, industrialists, and education specialists, this thesis provided a valid argument to call for stronger governmental intervention in the labor market and education. According to an extreme version of this view, the state should step in and participate more actively in deciding whom, how, and what skills the educational system should teach. This conclusion fits many vested interests since bureaucrats always want to acquire more redistributive power and employers seek ways to shift some training costs onto the state budget. These ideas, which concern the interests of millions of citizens in the country, assume that significant budgetary funds may come up for grabs. Hopes of various social groups for being allowed to share the pie shape the social consensus on relevant policies. This concentration of vested interests is not unique to Russia and was mentioned by R. Freeman in relation to the US. ${ }^{23}$ Since the outcomes of such policies take years to be seen, their lobbyists do not expect any personal responsibility for plausible misadvise. That is why the thesis on labor shortage deserves to be carefully scrutinized and cannot be taken for granted.

In the 2000s, as labor shortage claims were loudly heard in many transition countries, it would seem logical to consider all these cases together. ${ }^{24}$ However, this would be erroneous. If in the CEE countries that joined the EU the labor shortage could emerge as a consequence of the accession and subsequent out-migration to more developed EU states, the Russian situation was somewhat different. Unlike the new EU countries, Russia enjoyed a certain increase in the efficient labor supply, but not a decrease. However, if separate EU countries are considered as "mega-firms", we can see some parallels with our story: labor shortage claims often come from the least efficient and competitive agents that are unable to offer competitive remuneration. State borders can hide the fact that complaints come from low efficiency areas.

At the moment of writing, the Russian economy (as well as all other major economies) was plunging into a deep economic recession. It is highly probable that the first reaction of the labor market will again be an accumulation of more excess labor. In any case, all institutional

23 Freeman, R. Is a Great Labor Shortage Coming? Replacement Demand in the Global Economy. Working Paper No. 12541, September 2006.

${ }^{24}$ Rutkowski, J. From the Shortage of Jobs to the Shortage of Skilled Workers: Labor Markets in the EU New Member States, Discussion Paper No. 3202, December 2007 
constraints and incentives that induced firms in the 1990s to underutilize their workforce are still in place. How firms with a shortage or excess of labor will react to the crisis remains to be seen.

What does our empirical study show? First of all, it reveals a sharp mismatch between the states of the labor market that have been painted by using "objective" indicators and by managers' self-reported perceptions. Managers are very much concerned with shortages of labor in general as well as by shortages of particular skills. However, the behavioral responses of their firms to tentative shortages do not provide any proof for this claim.

Managers that name shortage to be an investment constraint usually do not link it to the particular wage levels at their own firms, but rather explicitly recognize low wages as a factor contributing to shortage. Interesting nuances come with a more detailed analysis. Of those managers who complain of a shortage, only two thirds explain the shortage by a lack of needed skills in the market. Half of those who nevertheless claim a lack of needed workers in the labor market actually face no difficulties themselves in searching for and hiring new workers with the required characteristics. If these caveats are accounted for, the scale of expected labor shortage gradually shrinks and does not seem threatening anymore. ${ }^{25}$

Labor shortage is understandable if it emerges as a problem of rapidly expanding firms. If a firm grows too fast, it may face difficulties in searching for and hiring new workers with the needed skills, as this requires significant time and entails costs and thereby becomes an obvious constraint for further growth. Basically, the firm wants to get more than a tight labor market can offer. However, most Russian firms with a labor shortage tell us a completely different story, since they are more likely to downsize but not to expand. In general, they are inefficient and loss-making, they employ a low quality and low paid workforce, they are technologically obsolete and gradually losing jobs. This general conclusion emerges from the complex study of various associations between performance and an excess or shortage of labor.

Even more paradoxical is the fact that firms reporting a labor or skills shortage seem to expend little effort in solving the problem. In fact, they do little to attract new workers and to use working hours more efficiently; they under-invest in training and keep using a low-wage policy instead of trying to attract better workers through offers of higher wages and better training. The contrast between how much firms complain of a shortage of skills and how little they in fact do

${ }^{25}$ D. Mitchell, in discussing the labor shortage claims widely reported in the 80 s, also notes that a more accurate and detailed look at survey data dismisses these claims as groundless. (Mitchell, D., Wage Pressures and Labor Shortages: The 1960s and 1980s. Brookings Papers on Economic Activity, Vol. 1989, No.2) 
in order to fill the gap looms large and deserves a special study. ${ }^{26}$ Taken together, various pieces of the story hint at the fact that wage levels that can be significantly lower than outside options available to workers, largely drive the labor shortages in these firms.

How can we explain the sharp contrast between widespread beliefs and our survey-based conclusions? In a competitive market environment inefficient firms rapidly lose in the competition for better workers to more efficient firms, they tend to quit the market and their voice is not heard anymore. If firms are vocal in their shortage claims they are likely to be expanding quickly. The current Russian story is completely different. Market selection works poorly, thus allowing inefficient firms ("unburied but dead", according to B. Kuznetzov) that have been losing labor to remain afloat for long time. It is these firms that become the major disseminators of complaints of labor shortage. Since their population remains significant and they are often important regional employers, their voice remains undeservedly loud and pressures the government for state funded vocational training and other forms of assistance. Like a fog, this informational noise hides the real problems that more efficient firms may face.

Summing up this part of the story, it can be said that non-competitive, inefficient, and low wage firms are the most vocal in shortage claims. Their fragile market position explains why they are unable to raise their wages and why they keep losing jobs, while they benefit from the inefficiency of bankruptcy regulations that allow them to stay afloat. From a welfare point of view, it would be less efficient if they could hire as many additional workers as they want. In this respect, the problem of shortage emerges as a symptom of a severe institutional inefficiency.

Mass complaints of a shortage are only a part of the total picture. Our study shows that shortage claims in the Russian industry coexist with excess claims reported by a large segment of firms. Excess labor is also troublesome but is more likely to be an attribute of very large firms privatized in the 90s. For these firms, losing some fat is vitally important for retaining market competitiveness. Their downsizing is institutionally constrained by current employment regulations that seem to overprotect workers that are in excess in relation to expected output.

The main conclusion that emerges from this study is that difficulties for firms in maintaining the optimal employment mix are grounded in the institutional environment, which does not allow for a quick reallocation of labor from pockets of inefficiency to pockets with more efficient use. If this conclusion is correct, then any attempts to substitute a complex restructuring of market institutions with detailed governmental intervention into vocational

\footnotetext{
${ }^{26}$ H. Tan, Y. Savchenko, V. Gimpelson, R. Kapelyushnikov, A. Lukyanova. Skills Shortages and training in Russian enterprises, IZA DP 2751, April 2007.
} 
training will bring even more inefficiency and a further deterioration of the competitiveness of Russian industry.

We strongly believe that the major reason for widespread and loud claims of shortage in the modern Russian economy is not a physical shortage of labor, but rather weak selection mechanisms. Thus the key issue is not a shortage or excess of labor in the Russian market but an excess of nonviable firms and a shortage of highly efficient firms. This excess/shortage distorts the labor market. The major solution is seen in creating the institutional conditions that would stimulate a more efficient reallocation of labor. 